\title{
The Hajj in Early Photo Documents
}

\author{
C.E.S. GAVIN
}

Illustrations for this book were chosen by the author from among thousands of photographic records assembed over the past two decades to form a comprehensive visual encyclopedia for al-Haramayan, which is being prepared in close consultation with historians, architects, and elders of the Holy Cities. All illustrations have been prepared by Elizabeth Carella from copy negatives made by herself and William Corsetti, often from originals that were discovered and photographed in the course of inventories undertaken between 1983 and 1985 by the King Fahd Archive (KFA). Initiated with funds graciously provided by the Custodian of the Two Holy Mosques, the KFA grew out of the International F.O.C.U.S. Conferences convened in 1978 and 198I in Cambridge, Massachusetts. It was established on 2 September 1982 "to find and preserve previously inaccessible or endangered photo-collections important for the history and cultural heritage of the peoples and places of the Middle East." Preliminary reports of KFA results have been issued in Museum (UNESCO) 37, no. I/no. 145 (1986), 4-12, and in "Photography and Social Sciences-In Light from Ancient Lands," in The Invention of Photography and Its Impact upon Learning, edited by L. T. Amber and M. Banta (Cambridge, Mass.: Harvard University Library, 1989), 48-6I. The first formal publication of KFA inventories appeared as Imperial Self-Portrait: The Ottoman Empire as Revealed in the Sultan 'Abdul-Hamid II's Photographic Albums Presented as Gifts to the Library of Congress (1893) and to the British $\mathrm{Mu}$ seum (I894), edited by C.E.S. Gavin as a special volume (xII) of the Journal of Turkish Studies in 1989 (for a brief review of pre-photographic visual records for the pilgrimage to Mecca, see especially pp. 13-16).

From Islamic sources, we have highly diverse yet quite informative diagrams for pilgrim encampments and other aspects of the Hajj, such as those preserved in the library at Topkapi (as reported in Journal of Turkish Studies 7 [1983], 407-413). From Occidental travelers come careful pictures made on the spot: in 1762 on the Red Sea by Georg Bauernfeind, who accompanied Carsten Niebuhr; in 1778 in both Mecca and Medina by an anonymous Stambouli painter who accompanied the Ottoman general chosen to serve as Amir al-Hajj; and in Mecca in 1806 by the highly trained Ali Bey al-Abbassi.

The Begum of Bhopal seems to have been the first pilgrim to have published an account of her Hajj (1868?) illustrated with photographs, 
although none of them were made in Arabia. In 1873 the painter and scholar Osman Hamdi Bey published the first photo records of traditional Hijazi dress (worn by photographic models posing in Istanbul). Photographic reports from the Holy Cities themselves began in I880 with the glass plates exposed by the Egyptian colonel M. Sadic Bey after he obtained permission from the Sharif Awn al-Rafiq.

In presenting these early photo documents, we wish most specially to express our gratitude to Dr. E. van Donzel, the editor-in-chief of the Encyclopedia of Islam, who, as president of Het Oosters Instituut in Leiden, has graciously permitted us to reproduce precious documents assembled by his late predecessor Professor C. Snouck Hurgronje.

\section{EARLY PHOTOGRAPHERS OF THE HAJJ}

M. Sadic Bey (1880). An eminent cartographer who had researched the tribes and roads of the Hijaz for decades, Mohammed Sadic (he seems to have preferred this form for the Roman alphabet but also spelled his name Sadik and Sadiq) made the photographs published here while a colonel in the Egyptian army (with the honorific "Bey"). In I88I he published his views in portfolio format on the occasion of the Third International Congress of Geographers in Venice, where his work was awarded a medal. Subsequently, Sadic Bey was elected president of the Khedival Geographic Society, and he eventually retired from the military as Liwa (Lieutenant General) M. Sadic Pasha.

Bilderatlas (pre-1889, mostly 1884) and Bilder aus Mekka (pre-1889, but after $1884 / 5$ ). Both of these books were published in 1889 by C. Snouck Hurgronje to accompany his Mekka. Bilderatlas, which contains lithographic reproductions of Sadic Bey's photographs and color plates of Meccan objects, primarily features pilgrim groups photographed by Snouck himself, often at the Netherlands Consulate in Jidda. Bilder aus Mekka consists entirely of photographic plates that were sent to Snouk after he had left Mecca and that reached Leiden too late for inclusion within the Bilderatlas portfolio. The creator of those valuble pictorial documents, whose name Snouck never mentions, was Al-Sayyid Abd alGhaffar.

Al-Sayyid Abd al-Ghaffar (from 1884 on). In 1981 F.H.S. Allen and C. Gavin first identified the earliest Arabian photographer by deciphering his elaborately calligraphed signatures, which without exception had been erased from the plates reproduced by Snouck Hurgronje: "Futugrafiyat al-Sayyid "Abd al-Ghaffar, tabib Makka" (The Photography of the Sayyid 
Abd al-Ghaffar, physician of Mecca). This princely eye surgeon had been host to the young Snouck in Mecca immediately after the Dutchman's conversion to Islam. Snouck claimed to have taught his host how to use a camera and attributes to him (without ever mentioning his name) the pictures reproduced in Bilder aus Mekka. KFA teams have recovered scores of informal portraits made by the physician in Mecca subsequent to 1889 and sent on to Leiden by Dutch consuls.

H. Mirza of Delhi (pre-1904). This Indian photographer/publisher produced a series of twelve albumen prints, each surrounded by Urdu poetry elegantly calligraphed in red ink. They have survived in the collection of Fouad C. Debbas of Beirut, with whose gracious permission selected exemplars have been here reproduced. The date for Mirza's work has been suggested by Professor Ali al-Asani, who has prepared translations of the Urdu. Al-Asani noted that the texts do not contain any reference whatsoever to the Hijaz Railway, as one would have expected after 1904, since monetary contributions for that project had been extensively solicited among Indian Muslims from that date onward.

Rif ${ }^{c}$ at Pasha (pre-1925). In 1925 Liwa Ibrahim Rif at Pasha published his two-volume work Mirat al-Haramayn (Mirror of the Two Sanctuaries) at Cairo's National Library Press. Frustrated at his inability to describe adequately the inspiring sites he saw on his I9OI Hajj, the general decided to learn to take photographs himself. He could then make a pictorial record of his subsequent pilgrimages, because "however precise my verbal descriptions I could never have been able to depict the whole truth nor fascinate you in any way [as effectively] as looking and beholding can." 
